\title{
Guide to Terms
}

\section{Appellation wine}

Also referred to in this book as luxury or "quality" wine. Wine that comes from state-approved grape varietals and vineyards in officially designated wine regions. Appellation wine is place-specific, as opposed to "industrial wine," which can come from anywhere. Most of the metropolitan policymakers discussed in this book assumed that appellation wine and quality wine were synonymous, an assumption that reflected and perpetuated class and racial biases against peasant and Algerian producers.

\section{Beet grower}

These cultivators often turned their beets into either alcohol or sugar. They were loosely allied with the industrial vine growers in obtaining state subsidies to cope with the problem of overproduction.

\section{Cider producer}

Farmers with an orchard, mostly in Brittany and Normandy, who turned their apples into cider. Cider producers joined forces with industrial 
vine growers and beet growers in persuading the state to subsidize their surpluses.

\section{Home distiller}

Found throughout France, these farmers and gardeners distilled the fruits of their own property into brandy. Although much of their production took place on a small scale, home distillation was also a way for vine growers and cider producers to find outlets for their surpluses. The state allowed 10 liters of tax-free home-distilled brandy per year.

\section{Industrial wine}

Also referred to in this book as "ordinary wine," "table wine," or vins de consommation courante. Wine that came from high-yielding vines produced in the plains of the Languedoc that tended to be acidic and low in alcohol, was often deemed to be of inferior quality, and was blended by merchants with mass-produced, more alcoholic wines from Algeria and Italy. Consumers often preferred the wines that fell under this category, but state officials subordinated these wines as "ordinary" given their links to peasants in mainland France and settlers in French Algeria, two groups that policymakers wished to reform. Unlike appellation wines, which are branded with their place of origin and style of production, industrial wine used a corporate trademark such as Postillon or Préfontaines, not all that different from Coca-Cola.

\section{Merchant}

Middlemen or négociants who sourced grapes from different areas, usually with the purpose of making cheap industrial wine.

\section{Plonk}

English slang that denotes low-quality, standardized, industrial wine.

\section{Technocrat}

Otherwise known as an expert. Technocrats are trained in France's elite institutions and staff the government administration. Although they are often perceived and portrayed to be ideologically and politically neutral, technocrats entered the policymaking process with their own cultural assumptions and political agendas. 


\section{Terroir}

A fluid term that loosely translates as "a sense of place." Appellation wines are typically seen as expressing terroir, a sense of how and where they are made.

\section{Vine grower}

Cultivator of vines, but not necessarily a winemaker. Although in appellation districts many vine growers also made their own wine, the vine growers of industrial wine, particularly in the Languedoc, often could not afford winemaking equipment and thus sold their grapes to merchants who blended them with the more alcoholic wines of Algeria and Italy. 



\section{The Sober Revolution}




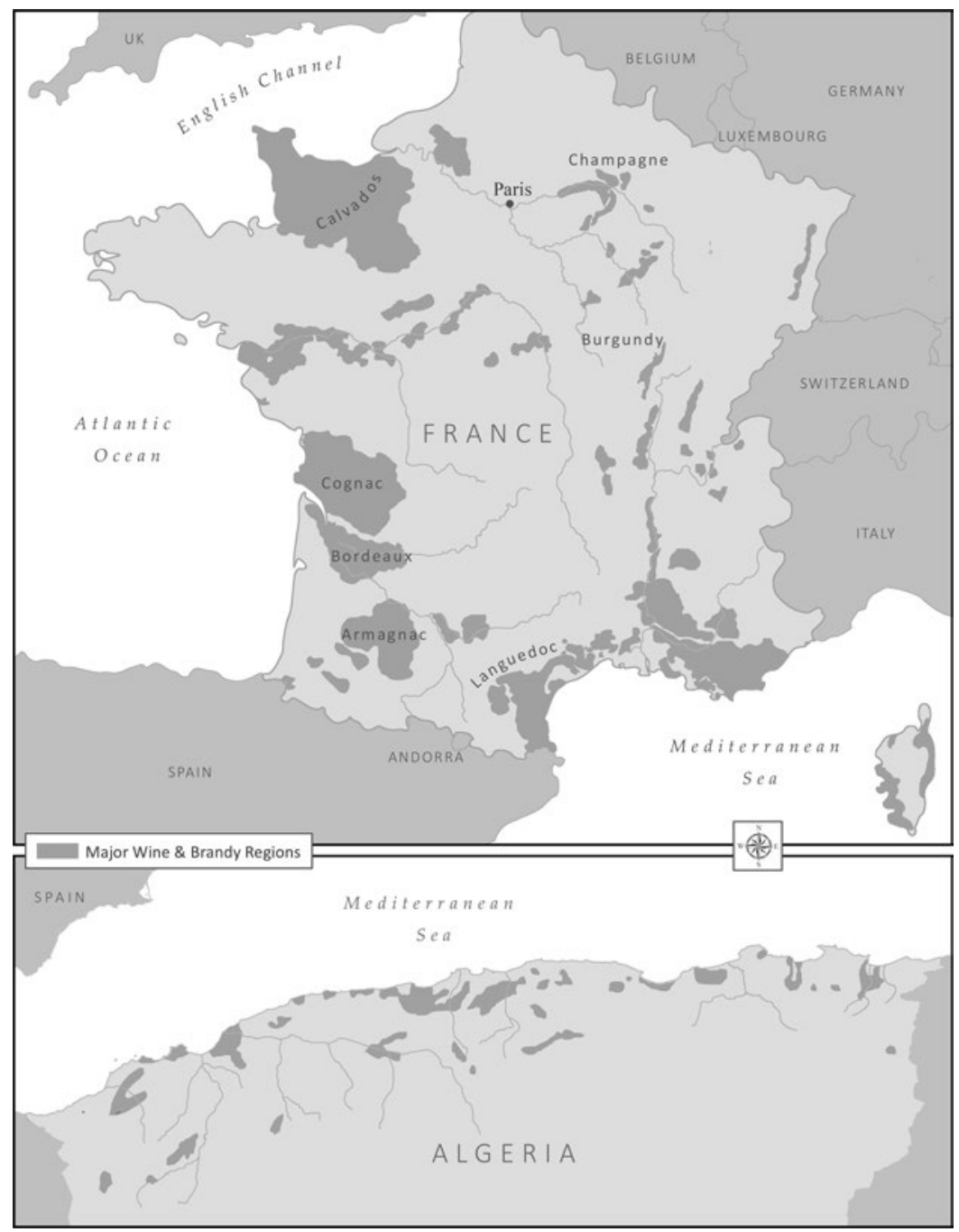

Figure 1. Map of major wine and brandy regions in France and French Algeria. Metropolitan policymakers generally did not distinguish among Algerian wine regions; for this reason these regions are not identified on the map. 